\title{
Religion and International Relations: What Do We Know and How Do We Know It?
}

\author{
Jeffrey Haynes
}

\section{check for}

updates

Citation: Haynes, Jeffrey. 2021. Religion and International Relations: What Do We Know and How Do We Know It? Religions 12: 328. https:// doi.org/10.3390/rel12050328

Academic Editor: Paul Morris

Received: 29 March 2021

Accepted: 6 May 2021

Published: 8 May 2021

Publisher's Note: MDPI stays neutral with regard to jurisdictional claims in published maps and institutional affiliations.

Copyright: (C) 2021 by the author. Licensee MDPI, Basel, Switzerland. This article is an open access article distributed under the terms and conditions of the Creative Commons Attribution (CC BY) license (https:/ / creativecommons.org/licenses/by/ $4.0 /)$.
School of Social Sciences, London Metropolitan University, London N7 8DB, UK; tsjhayn1@londonmet.ac.uk

\begin{abstract}
The article surveys the recent scholarly study of religion and international relations/International Relations (ir/IR). The focus of the article is on two discrete periods: pre-11 September 2001 ('9/11') and post-9/11. During the first time period, Iran's Islamic revolution (1979), the civil war in former Yugoslavia and Huntington's 'clash of civilisations' (1993) were major foci of attention. The second period saw a large number of scholarly accounts following the 9/11 attacks on the USA, with a sustained focus on the international securitisation of Islam. The article also briefly surveys the position of religion in IR theory. The article concludes that following the recent diminution of the threat to the West of Islamist terrorism-subsequent to the apparent demise of Islamic State and the fragmentation and dissipation of al Qaeda-the study of religion in IR theory needs to take better account of changing circumstances to arrive at an improved understanding of how religion impacts on international relations/International Relations.
\end{abstract}

Keywords: religion; international relations; international relations; clash of civilisations; 9/11

\section{Introduction}

Thinking about the association of religion and international relations, what do we know and how do we know it? In recent decades, much attention has been paid to how religion impacts upon international relations; not all of it has come from International Relations (IR) scholars. This may be because, as a discipline, IR was initially slow to take religion seriously, with many IR scholars apparently reluctant to accept religion's significance in IR and factor into their analyses. Reus-Smit notes that both religion and culture $^{1}$ were 'largely neglected' in IR until the al Qaeda attacks on the Pentagon and New York's Twin Towers on 9/11. Prior to 9/11, however, two developments also caught the attention of some analysts: Iran's Islamic Revolution of 1979 and Huntington (1993, 1996) 'clash of civilisations' paradigm; 9/11 significantly added to these, and together they have helped to sustain a focus on religion in IR over the last few decades. The topic first appeared of significance in IR because Iran's Islamic Revolution led to widespread apprehension that the new revolutionary government would seek to spread its radical agenda to the Muslim ummah via Iran's foreign policy, much as the post-revolutionary government in the Soviet Union had sought to spread its revolution six decades earlier to those it believed would respond favourably to its appeals.

A consequence of 9/11 and its aftermath-especially, the US-led 'war on terror' and increasing securitisation of Islam (Haynes 2018, 2019) — was an increased focus on religious ideas, especially Islamist extremism and terrorism. It also led to a renewed focus on Huntington's clash of civilisations paradigm, which focused on 'The West' and 'Islam' as radically different concepts, informed by dissimilar ideas and values. Each was constituted, according to Huntington, in relation to state power and "mobilized to sustain systemtransforming political projects, either on the part of liberal democracies, seeking to redefine the norms of sovereignty and global governance, or terrorist organisations seeking an end to the liberal capitalist world order" (Reus-Smit 2005, p. 211).

In addition, the last few decades saw a pronounced trend to proclaim a global religious resurgence and 'post-secular' international relations (Thomas 2005; Toft et al. 2011). This 
is not to assert that significant actors in IR have essentially changed in recent years: the terrain is still dominated by powerful states. Yet, in certain contexts and in relation to some issues, various religious non-state actors, including Islamic State, al Qaeda, and the Holy See, also need to be taken into account. On the one hand, states (or governments, both terms are frequently employed in the IR literature) in various ways, contexts and with assorted outcomes, may link policies to overtly religious concerns so as to justify or legitimate specific foreign policies, such as the sustained US support for international religious freedom since the Clinton presidency in the 1990s. On the other hand, as already noted, non-state actors may also, at times, be significant for our understanding of the role of religion in international relations.

Building on Huntington $(1993,1996)$ analysis, Thomas (2005) focuses on non-state "religious traditions or movements" which affect international relations in three main ways: impact on international conflicts, for better or for worse; seek to change international society's norms, values, or institutions and help amend a state's foreign policy. On the first point, the nature of international conflict changed since the end of the Cold War, characterised by a relative scarcity of interstate wars and more intrastate conflicts. For example, in the 1990s, there were more than 100 major conflicts, with over 1000 fatalities in each, but only a handful were interstate wars. Instead, most were intrastate conflicts; one in 14 (7 percent) were judged to be 'communal' wars, with prominent religious, 'cultural' or ethnic division and strife. To some extent, such communal issues replaced extant secular ideologies-including, communism and socialism — as key sources of identity, competition and conflict in international relations. The widespread eruption of communal conflicts cast serious doubt on the potential to move from the bipolar Cold War order-rooted in secular ideological division - to a new configuration characterised by (the pursuit of) peace, prosperity and cooperation. These concerns were highlighted in the brief focus on a 'new world order' highlighted by US President George H. W. Bush in the early 1990s. The focus was, however, short-lived, as the inter-communal wars in former Yugoslavia of that decade, as well as Iraq's invasion of Kuwait and the West's punitive response, highlighted the return of communal strife and made achievement of a new world order impossible. Thomas' analysis was highly influential in developing attention to religion's presence in IR and today, more than 15 years after publication, is still widely regarded as a benchmark in the development of our understanding of this phenomenon. ${ }^{2}$

While it is not always regarded as a significant component of religion's return to international relations, the civil war in former Yugoslavia (1991-2001) is one of the most important events to reignite interest in national and international relationships involving culture, ethnicity and religion. The civil war in former Yugoslavia-between Muslim Bosnians, Catholic Croats, and Orthodox Serbs-drew in jihadis, the Holy See and Moscow, and, in effect, was a new "hot" war in microcosm focusing on culture, religion and ethnicity/nationalism). This was not widely foreseen by IR researchers who tried to apply traditional IR paradigms to explain the changes. Maybe we should have seen this coming, given that the Soviet Empire had been undermined a few years earlier by rising religion, culture and ethnicity/nationalism in previously loyal satellite states, such as Poland. These changes and their aftermath took the attention of researchers, including Huntington, to the role of religion in IR in the early 1990s, but it took 9/11 to fully to cement this attention.

Religious differences were key to the Yugoslavia conflict, similarly as they had been to the earlier conflict between Iran and Iraq (1980-1988), the most destructive (of life) conflict since World War II. ${ }^{3}$ In both wars, religious differences were central to engendering and influencing individual and group values-factors that can affect formulation and execution of states' foreign policies, as the Iran-Iraq war demonstrated. This is because religion is an important source of basic value orientations both for individuals-including political leaders-and for communities in countries around the world. This can clearly have major social and political connotations, enabling religion to be "a mobiliser of masses, a controller of mass action ... an excuse for repression [or] an ideological basis for dissent" (Calvert and Calvert 2001, p. 140). 
Second, Thomas notes that the relationship between "international society" — defined as the free association of autonomous countries engaging on the basis of shared interests, values, and norms - and internationally-significant non-state religious actors was also a significant issue after the Cold War. Finally, several states are noted for the overt intrusion of religion into their foreign policies in recent decades, including Turkey and the USA (Öztürk 2021; Haynes 2021).

We can draw several conclusions from Thomas's comments. First, in recent years, the association of religion to both state and non-state actors' policies and actions have become important for understanding international outcomes in many parts of world. This is a novelty, because International Relations has long seen the international system as a demonstrably secular one. The fundamental secular norms of international relations were enshrined in the Treaty of Westphalia (1648) — particularly the notion of state restraint in religious matters, and the gradual privatisation of the latter, implying political marginalisation. This encouraged a strong belief among most IR scholars that international relations discourse is predominantly secular. Second, religion influences international outcomes involving international society. Finally, all religious actors' influence in international relations is linked to their ability to exercise ideational power. Both states and non-state actors can be influential in this regard. Toft et al. (2011) share these concerns, assessing whether religion is a force for good or evil in world politics. The not very surprising conclusion is that it can be both, depending on the actor, the circumstances and the context.

The current article surveys the recent scholarly study of religion and international relations/International Relations' (ir/IR). ${ }^{4}$ The focus of the article is on two discrete periods: pre-9 September 2001 ('9/11') and post-9/11. During the first time period, Iran's Islamic revolution (1979) and Huntington's 'clash of civilisations' (1993) were major foci of attention. The second period saw a large number of scholarly accounts following the 9/11 attacks on the USA, with a sustained focus on the international securitisation of Islam. The article also briefly surveys the position of religion in IR theory. The article concludes that following the recent diminution of the threat to the West of Islamist terrorism-subsequent to the apparent demise of Islamic State and the fragmentation and dissipation of al Qaeda-the study of religion in IR theory needs to take into account the changing circumstances to arrive at a better understanding of how religion impacts on international relations/International Relations.

The research design of the article is to assess the significance of religion in international relations over time, both in relation to empirical events and to IR theory. Regarding the first-empirical events - the article claims that what happens in the 'real world' in relation to religion's role in international relations, is the main driver of developments in IR theory associated with religion. For example, Iran's Islamic revolution in 1979 led to a focus on the international effects of the revolution, via Iran's foreign policy, while 9/11 galvanised two decades of focus-some would say obsession-with the impact of Islamic extremism and terrorism as it affected international relations. Therefore, the time period the article examines is post 1979-it focuses on certain significant events during that 40-year period; and briefly examines how IR theory has sought to incorporate those events into its understanding. In other words, reference to 1979 underlines the importance of a long-term approach to understand IR's engagement with religion. Several contributors to this debate are focused upon in this article, including Sandal and Fox, Thomas, Huntington, Kubálková and Hurd. They are selected because of their theoretical and empirical importance: these are the people most often cited in assessments of religion in ir/IR and, as such, it is appropriate to look at their arguments in some detail. The overall 'point' of the article is however modest: it seeks to organise and, to a limited degree, deepen existing knowledge about research on religion in IR and the role of the state in this context. Hopefully, this would motivate other researchers to develop related knowledge further. 


\section{Religion and International Relations: Who Cares and Why?}

Recent discussion on the 'Religion and International Relations' Facebook page https:/ / www.facebook.com/groups/336226026577855 (accessed on 7 May 2021) and on the 'Religion and International Relations' website https:/ / religion-ir.org/ (accessed on 7 May 2021) indicates that the subject matter of religion and international relations is not fixed but varies widely among those interested in the topic. Related scholarship focuses on, inter alia, new, more quasi-religious frames to foreign policy issues linked to ascendant neo-nationalist and populist political parties in Europe, Turkey and elsewhere (Haynes 2021; Cesari 2021; Öztürk 2021). Others point to how intersectional identities of gender and religion impact women's experience in times of conflict and political violence where religious narratives are used to justify the conflict or mobilise supporters (Jenichen 2021). Transnational religious activism (for example, churches in the US lobbying in Uganda on gay rights issues) also takes scholarly attention, as does the topics of religion and the climate emergency and the role of religious movements in disaster relief (Marshall 2021). A further topic also engaging attention is the resurgence of civil religion and its surprising alliance with traditional faiths, a consequence of the increasingly blurred line between the 'religious' and the 'secular' as, for example, expressed in novel expressions of "Christianism" in Europe (Brubaker 2017) and the USA (Haynes 2021; Ryan 2021), and in nativist religious traditions around the world (including in India), amalgams of nationalism, religion, and cultural myth (Religion 2021). Here, the focus is on how religion and politics frequently cut across the national/international divide, implying overlap between the domestic and the external.

These are wide-ranging concerns, and it seems clear that the rather single-minded fixation on 9/11 and its aftermath is now past. The current situation of diverse foci in analyses of religion and international relations contrasts with the position in the recent past, where most attention was on the threat to international order and stability from Islamist extremism and terrorism. The lack of a common focus in the current study of religion and international relations has not prevented it from becoming an established, albeit still quite marginal field of study within the discipline of International Relations. This can be shown in two main ways. First, the topic has recently become an institutionalised subject area within the IR scholarly community. For example, the US-based International Studies Association (ISA), the world's largest professional gathering of IR scholars, established a dedicated section-'Religion and International Relations', known for short as REL-in 2013. In 2021, REL had 212 members-a relatively small section of the ISA, with its overall 5500 members, that is, 3.8\% (2021 data). This confirms that there is a small percentage of ISA membershalf of whom are based in North America, with the rest located elsewhere in the world, mostly in the Global North with relatively few in the Global South-interested enough in studying and researching religion in international relations to pay USD 5 annually for REL membership, in addition to the yearly cost of ISA membership, typically USD 100 or more.

Another way of gauging the importance of a topic is: Does it have a dedicated scholarly journal? Religion and international relations has one such journal: The Review of Faith and International Affairs (RFIA), whose website proclaims it is an "international journal publishing innovative research and policy-relevant analysis on the role of religion in global affairs and public life worldwide" https:/ / www.tandfonline.com/toc/rfia20/ current (accessed on 7 May 2021). In 2021, RFIA was in the 19th year of publication, with four issues a year. The four most read RFIA articles were, in March 2021: "Culture, Religion, and Freedom of Religion or Belief"; "Economic Impacts of Child Marriage: A Review of the Literature"; "Child Marriage: A Critical Barrier to Girls' Schooling and Gender Equality in Education"; and "Introduction: The "Clash of Civilizations" and Relations between the West and the Muslim World". It will be noted that only one of these 'most read' articles focused on one of the core topics within religion and international relations: the 'clash of civilisations'. It suggests that most attention from RFIA readers is on non-traditional topics: freedom of religion, culture, child marriage and education. Moreover, over its two decades of existence, very few articles in RFIA have focused on theoretical issues in the study of 
religion and international relations. It seems clear that RFIA is a journal most interested in religion-in-international-relations not religion-in-International Relations. What does this tell us about the position of religion in IR theory?

\section{Religion in International Relations Theory: What Do We Know and How Do We Know It?}

Forty years after Iran's Islamic Revolution, three decades after Huntington (1993) much-cited article in Foreign Affairs, "The Clash of Civilizations?" and 20 years after 9/11, what IR scholars are studying when they examine 'religion' is varied. The REL section of ISA was founded following the efforts of Ron Hassner, a professor at UC Berkeley, whose research interests are, as listed on his Google Scholar page: international security, religion and international affairs, religion and conflict, and Israel studies https:/ / scholar.google. com / citations? user $=$ odF2zi8AAAAJ\&hl=en (accessed on 7 May 2021). ${ }^{5}$ Hassner's research profile is typical of many scholars, especially those based in North America, who focus on the topic of religion in international relations. Many are concerned with international conflict and security studies, often focusing on Islamist extremism and terrorism. Others, including Thomas (2005), Dallmayr (2004) and Petito (2009) are more interested in the role of religion in international co-operation, in relation to, inter alia, efforts to tackle pressing global problems, such as: human rights, the climate emergency and barriers to improved international religious freedom. The latter issue, in particular, receives much attention from IR scholars, including RFIA, especially those located or interested in the USA, where successive presidents_from Clinton (1992-1998) to Trump (2017-2021) — made it a key concern of US foreign policy. 6

Such scholars do not, however, share a theoretical understanding of how religion influences outcomes in IR. Mainstream and established theories and paradigms-including realism, liberalism, critical theory and constructivism, do not consistently consider religion in their analyses. Why? For many:

The assumption that the religious revival in today's world heralds a new era is not supported by the evidence. Data and analysis both suggest a continuing, complex, hierarchical and multipolar, but also interdependent and multilateral, global system. Those acting under the inspiration of a creed will, in the long run, have to adapt to the secular concepts that underpin the foundations of the world order rather than the other way around (emphasis added; Merlini 2011, p. 127)

Merlini mentions the inspiration of a "creed" in understandings of the world. What is a creed? It is a belief, particularly a religious one. An example of a creed is faith in the Christian religion, expressed in the 'Father, Son and the Holy Spirit. Unlike 'hard-headed' realists with their positivist take on how the world works, those influenced by a 'creed' are indulging in unwarranted faith that the world can be improved by religious efforts. There is a pejorative connotation to Merlini's comment, underlining a common understanding of many 'mainstream' IR scholars, that religion is destined to fade from public prominence in line with the modernist 'creed' of secularisation theory.

Nevertheless, the fact that religion did not fade from public prominence ensured that its role in international relations would require a theoretical understanding to explain this outcome. Over the last two decades, scholars have sought to develop theories of how we should understand the role(s) of religion in international relations (including Fitzgerald 2011; Fox and Sandal 2013; Huntington 1993, 1996; Hurd 2008; Kubálková 2000; Thomas 2005). Contrary to the already-noted assertions of Merlini, Snyder (2011) claims that "Religious concerns stand at the center of international politics'. However, if religion stands at the 'center of international politics;' then it cannot be of such unimportance that 'secular concepts [still] underpin the foundations of the world order". Both cannot be right! Merlini is claiming that although there is 'more' religion in international relations compared to the past, this does not imply that we need to change how we understand how the world works because it is relatively inconsequential compared to traditional forms of influence, such as military, financial and diplomatic power. Snyder begs to differ. 
It would be very difficult to claim authoritatively that the fundamentals of international relations have decisively changed as a result of what some see as a near-global religious resurgence. In this regard, there is no compelling evidence of which I am aware that 'post-secular' international relations is substantially different from 'secular' international relations, which evolved following the Peace of Westphalia in 1648. How do we resolve this conundrum: that is, religion is significant in understanding international relations versus religion is insignificant in understanding international relations? To examine this question, this section briefly surveys how 'religion' is understood theoretically within the discipline of IR, concisely looking at the work of several leading IR scholars in this regard.

Some scholars criticise the discipline of IR for ignoring or downplaying the impact of religion in international relations. The claim is that inadequate theories lead to inadequate policies, which may have dramatic consequences. For example, as Pollinder (2021) notes, if the United States government led by President Jimmy Carter had taken the role and significance of religion more seriously, the Iranian Revolution of 1979 might not have come as such a surprise, and with such major-and continuing - effects on US foreign policy under successive US presidents.

Do we need a new theory to satisfactorily explain how religion influences outcomes in international relations or can existing theoretical frameworks tell us what we want to know? Three of the most significant theoretical approaches applied to the study of international relations-realism, liberalism and constructivism-all struggle to factor religion into their paradigms. As Snyder (2011, p. 1) puts it, "the main canonical works of international relations theory, which continue to shape much empirical academic work, hardly mention religion".

The relative inattention can be explained in part by the fact that some prominent international relations scholars do not believe it necessary or appropriate to amend their normal conceptual frameworks by incorporating religious concerns into their analyses. None of the foundational accounts of the three main IR paradigms-that is, (Kenneth Waltz [1979] 2010) in relation to realism, Michael Doyle (1986) and Robert Keohane (1984), focusing on liberalism, and Alexander Wendt (1999) on constructivism-pay any attention to religion, presumably deeming that it is too unimportant to warrant their attention. Realists ask: How many divisions has the Pope? This refers to the notion that the soft power of religion cannot hope to be a plausible counter for military force's hard power. For their part, Liberals seem to accept the major claim of secularization theory: religion is declining as a public actor and as a result is becoming irrelevant in international relations. Finally, constructivism sees a central role for identity, norms and culture. Potentially, it is a more fertile environment to include religion analytically; it is strange, then, that Wendt fails to mention religion in what many regard as his field-defining contribution (Wendt 1999). Another prominent constructivist, Vendulka Kubálková, tried to factor religion into constructivist analysis with, as we shall see, mixed results.

In short, the three main IR theories say little or nothing about religion. To some extent, this was because much of the definitive work in this regard was published prior to the intrusion of religion into IR from the early 1980s; certainly, it was before 9/11, which led to an explosion of interest. In addition, the lack of concern was linked to the background, history and development of the discipline of IR, which occurred in the context of an overtly secular international environment following World War One. More generally, for long periods, international relations, especially in the West, was both statefocused and non-religious in outlook. Very few states-especially in the secular Westconsistently expressed an organising ideology which consistently involved religion. Instead, secular ideologies, such as liberal democracy, capitalism, socialism, social democracy and communism, were paramount. However, as Snyder notes, things clearly changed with $9 / 11$.

Since 11 September 2001, religion has become a central topic in discussions about international politics. Once Islamic terrorism put religion in the international 
spotlight, this realm suddenly seemed to teem with lively issues: the foreign policy predilections of the [US] Christian Right towards Israel and Southern Sudan, the complications of faith-based Western activism abroad, the Dalai Lama and the Falun Gong as potential destabilizers of officially atheist but increasingly neo-Confucian China, and the Myanmar military regime's fear of a potential alliance of Burmese monks and international refugee organizations. Perhaps religious international politics had been there all along, but it suddenly became harder to ignore (Snyder 2011, p. 1)

Snyder mentions three of the world faiths-Buddhism, Christianity and Islam. We could add both the influence of Hinduism in India's foreign policy, especially in relation to (Muslim) Pakistan during the rule of the Hindu nationalist Bharatiya Janata party, both in the late 1990s and at the time of writing (mid-2021), and that of Jewish political parties in Israel regarding the mainly Muslim Palestinians and the status of Jerusalem, a holy city for Jews, Muslims and Christians. Overall, there was a significant shift in world politics post-9/11, leading to increased attention to religion in the perceived shift to 'post-secular' international relations (Habermas 2006; Barbato and Kratochwil 2008). While such a shift is open to question and still controversial, the apparent resurgence of religion has been noted on many levels of social activity-including international relations/International Relations. Overall, this significantly undermines the deep-rooted, secular stubbornness of Western social sciences to take religion seriously.

As the 21st century progresses, there is growing attention on cultural ${ }^{7}$ explanations for outcomes in international relations. They have been highlighted in the reorganisation of world politics that followed the end of the Cold War and the associated impact of deepening globalisation - the work of Huntington is a key example in this regard. As Brown $(2005$, p. 48) notes, "theorists of globalization reject the state-centrism involved in many IR approaches in favour of an approach that stresses global social, economic, cultural and political forces". This encourages some IR theorists to engage with the issue of 'cultural globalisation' as a central facet of globalisation more generally (Beyer 2014). This issue also highlights the hitherto Eurocentric nature of IR theory and suggests that to understand religion in IR theory more generally, we need to bear in mind that the intrusion of new global actors into international relations implies that our theories to understand IR need to change too. Early thinking and argumentation about globalisation tended to focus on supposed cultural changes brought about by the sudden near-global dissemination of identical consumer goods and a 'Westernised'—or, American(ised)—cultural intrusion. Publicised by Western - especially, US-based transnational corporations- to Latin America, Asia, and elsewhere in the global south, it was widely asserted that cultural Westernisation/Americanisation fatally subverted local cultures, by encouraging local people to become 'consumers' of Western goods and services to the disadvantage of those produced locally. Together, the 'media revolution' characteristic of post-Cold War globalisation and the growth of consumerism help swiftly to undermine formerly autonomous cultures and values, replacing them with a Westernised 'global culture' of Hollywood, McDonald's, Coca-Cola, and Microsoft. Some also comment on the impact of American evangelicals spreading 'Americanised' brands of Christianity to the global south (McAlister 2018)

Representative of the first 'wave' of critical analysis of globalisation, Saurin (1995, p. 256) contended that individualistic cultures had the potential of being a major political force, to the extent that they would threaten both the basis of the existing divided state system and nationalism, its major supporting structure. Saurin asserted that the reason for this was that "culture avoids being located and tied down to any definable physical space". On the other hand, both nationalism and ethnic awareness are, at the same time, significant cultural components disseminated around the world, to become both a globalised and a globalising phenomenon. One of the main causes of contemporary ethnic and religious conflict in many countries, such as former Yugoslavia and India, is awareness, via globalisation, of what other groups around the world are doing, and with 
this knowledge, seeking to emulate their counterparts' struggles for greater power in relation to their own countries in relation to an identified 'other'.

Central to dissemination around the globe of what some claim is an increasingly globalised culture and ideas is individualistic, rather than communal, values. This is noticeable in the widespread clamour for more and improved (individualistic) human rights. To be sure, some entities, such as Islamist extremists and terrorists as well as some Asian governments, including that of China, seek to counter this development; therefore, it is difficult to deny that human rights issues are now widely perceived as worldwide problems, necessitating global solutions. This stimulated the development of international organisations and institutions seeking to address such issues; some are religious, either inter-faith or linked to a specific creed. This development has also fuelled the development of global or transnational civil society, whereby cross-border groups and grassroots organisations from all parts of the world interact in pursuit of certain international outcomes (Haynes 2012).

This has come in the context of the post-Cold War revival of 'identity politics'. A striking feature of the post-Cold War era is the increasing number of people who adopt a social, political and cultural identity based on, but not necessarily restricted narrowly to, a specific and autonomous religious creed. These include Islamists of various kinds, Christian evangelicals, and Christian, Hindu, Buddhist, Jewish and Sikh nationalists. Clearly, identity matters; in IR theory, constructivism has done some regional studies, such as that of the Middle East and that of South Asia, a service in providing an influential theoretical approach to understanding regional outcomes. On the other hand, constructivist accounts often overlook the material context of identity and, as a result, are as mistaken as materialist attempts to reduce it to only a minor issue. This is because material and normative variables are autonomous, while a steady social order depends on an interactive, relatively harmonious relationship. Hinnebusch comments that

When norms do not correspond to material structures, the former lack the material anchor to endure and the latter the legitimacy to survive without the continual application of coercive power. Arguably, the main source of the enduring instability of the Middle East is the continuing contradiction between externally imposed structures (the fragmenting states system, the region's international dependency) and the region's Arab and Islamic identities (Hinnebusch 2005, p. 170).

To comprehend this dynamic, it is useful to utilise a theoretical approach that is informed by material structures and norms and their interaction with interests and identity; to do this, we need to bridge the constructivist-materialist division. One compromise might be to employ constructivist methods as the first stage in tracing how domestic identity shapes states' conceptions of their interests. This might be more fruitful than starting from the position that states' wealth and power is the primary component of their regional or global position before adding further dimensions such as nationalism or religion to help shape a notion of interest putting a high value on regional autonomy.

In sum, post-Cold War globalisation is widely linked to metaphors such as 'the hollowed out state' and 'a borderless world'. The main focal point is, of course, countries' changing economic, political and cultural arrangements. The outcome is a reduction of what was once believed to be a primary attribute of statehood: a country's 'hard' boundaries and associated ability to control domestic environments. The implication is that globalisation undermines governments' ability to make autonomous, definitive decisions regarding their course of action. Put another way, the 'globalisation thesis' is destructive of the main fundaments of IR analysis. This is that the globe is filled with: (1) autonomous political territories presided over authoritatively sovereign, national governments (2) nation-states and (3) national economies. Collectively, they were understood to be the 'natural', worldwide units central to understanding how political and political economic arrangements 'worked'. The globalisation thesis significantly questions these long-standing assumptions.

Questioning state-centric dominance of international relations theory necessarily highlights the potential significance of non-state actors, both secular and those motivated 
by religion. It also leads to a focus on significant transnational networks which can affect international outcomes. Students of IR have long been aware of the claim that the 'nationstate is in retreat'. As long ago as the late 1960s and the 1970s, the question was asked in the IR literature if the state was 'becoming obsolete'? There was no conclusive answer, but it did not stop the question being asked over time. There were various points of view, including the state-centric (or billiard ball) international model and the 'cobweb' model, informed by the understanding that the state's autonomy was being significantly affected by burgeoning transnational connections between people and organisations. Later, in the 1980s, the state made a comeback. IR specialists saw, for the most part, that it was still highly significant. Later, in the 1990s, as already noted, the globalisation thesis once again questioned the significance of the state and its autonomy, with some claiming that burgeoning global civil society further undermined the state's ability to dominate international relations (Haynes 2005).

How might religion be brought into, and augment and illustrate, existing concepts, theories, or paradigms of international relations? Or, do we need new ones as a result of the wide-ranging concerns of religion and international relations in the third decade of the 21st century? In Religion and International Relations Theory, Fox and Sandal (2013) suggest that religion can be incorporated into mainstream IR theoretical paradigms: realism and liberalism. Sandal and Fox's analysis seeks to accommodate the varying ways that religion impacts on international relations by adapting IR analysis to incorporate religion. They seek to develop a wide-ranging analysis whereby religion affects outcomes in international relations in various ways, then assess what they have discovered in relation to how the various facets of religion can be explained by use of mainstream - that is, secular-IR theories. For Troy, the outcome is interesting but undermined by the approach of Fox and Sandal, which he claims is 'inevitably reductive', providing "sometimes idiosyncratic readings and interpretations of the already existing theoretical framework ... for example, Realism" (Troy 2015).

For Scott Thomas (2005), things need to be looked at differently. Published in 2005, Thomas starts his book by describing three (relatively) recent events of significance for analysis of religion and intranational relations: the Iranian Revolution (1979), the Polish "Revolution" (1989) and 9/11. He shows that in each case, policymakers and practitioners were informed and guided by secular explanations. As a result, they overlooked religious aspects of international affairs and failed to address them adequately. For Thomas, this demonstrates the heretofore marginalisation of religion and culture in international relations, and the importance of consistently factoring in such concerns into analysis. A later contribution from Thomas (2014) underlines that the 'religious' and 'secular' spheres are not two absolutely distinct configurations of power. Instead, "What counts as religious, secular or political in any given context is not only socially constructed; it is a function of different configurations of power surrounding the construction of the categories the religious, the secular and the political—and the boundaries between them" (Thomas 2014, p. 317).

Samuel Huntington $(1993,1996)$ influential 'clash of civilisations' paradigm is notable for seeing religion and culture as a central component of a novel theoretical understanding of International Relations. For Huntington, religion/culture is so central to outcomes that they supplant existing paradigms and become the key explanatory variable for thinking about the issues. None of the 10 contributors to Snyder (2011) much-cited edited book on religion in international theory-all of them US IR experts-believe that this view is accurate. However, they do agree that the importance of religion: (1) in international relations has never been as marginal as secular-minded IR scholars would have it, and (2) has been growing in recent decades. For example, in many countries, especially but not only in the global south, religion is increasing its importance and profile, often as a form of populist politics which followed a general discrediting of secular political ideologies, such as 'African socialism', 'Arab socialism' and (unqualified) communism. 
Like Huntington, Vendulka Kubálková $(2000,2003)$ introduced a novel and extensive theory of religion into analysis of international relations. As with Huntington, she was also critiqued. For over 20 years, since an initial 2000 article in the IR journal, Millennium, Kubálková developed her paradigm of 'International Political Theology' (IPT). Kubálková's IPT is a particularistic approach to constructivism. For Kubálková, it is essential to consider an ontological distinction between two worldviews: the secular and the religious. She contends that this allows us to bear in mind that religious actors may see the world differently, compared to secular, often positivist, approaches in the social sciences. For Kubálková, the key difference is that religious worldviews recognise multiple realities not necessarily 'sensed' by non-religious approaches. Fitzgerald (2011) is a key critic of Kubálková's analysis. In particular, he takes issue with a central component of her approach: the division between secular and religious ontologies. Fitzgerald critiques Kubálková for what he sees as her" Christocentric assumptions" (162)," wild fabrications" (163) and "completely circular" arguments (Fitzgerald 2011, p. 164). In addition, Fitzgerald criticises Kubálková for her attempt" to identify the essential characteristics of 'religion,' and therefore of all 'religions'". Fitzgerald is pointing to a frequently expressed concern, shared by other analysts, such as Hurd (2008): it is futile to try to capture the 'essence' of all religions, as there is not one. In the view of Fitzgerald, this is conceptually impossible since some scholars of religion, including those interested in traditional Chinese religions, such as Daoism, and those who focus on Sanskrit origins of Hinduism and the characteristics of Tibetan Buddhism, "are themselves involved in complex published debates about the relevance or validity of the term 'religion'". This is in part a definitional issue and in part a comment about the claimed autonomy of religious and secular views. For Fitzgerald, these issues significantly undermine Kubálková's claim regarding a central ontological difference between secular and religious worldviews. While 'secular' religions, including: nationalism, communism, socialism and humanism, undoubtedly arouse both passion and intensity, Fitzgerald argues that Kubálková probably understands that pursuing this investigative line would ultimately "weaken her claim that religion and the secular are ontologically distinct" (Fitzgerald 2011, p. 163).

Elizabeth Shakman Hurd $(2008,2015)$ is another scholar who has introduced a novel way of thinking about religion in international relations. Hurd (2008) argues that the long-term value of a core concept and practice-secularism-in international relations can be usefully thought of not as an opposite-a mirror image-of religion but rather as an analogous kind of worldview that draws on and competes with religious views. This can be seen in both domestic and international contexts. In the latter, many states' foreign policies are overtly, explicitly and consistently secular. The main thrust of Hurd's theoretical repositioning highlights that the topic of religion is both ubiquitous and distinctive. This implies a conceptual readjustment to view international relations 'appropriately', without abandoning insights from IR's mainstream (secular) models. Hurd is critiqued by Philpott and Shah (2016, p. 385) when she claims that "the constructs of "expert" and "governed religion" presupposes that there are genuinely "lived" or "everyday" religious phenomena that are distinct, identifiable, and not pure constructs imposed from above". In Beyond Religious Freedom, Hurd (2015, p. 7) states that: "Religion does not stand outside or prior to other histories and institutions. Religious practices unfold amid and are entangled in all domains of human life, forms of belonging, work, play, governance, violence, and exchange. Religion cannot be singled out from these other aspects of human experience, and yet also cannot simply be identified with these either". However, this does not convince Philpott and Shah (2016, p. 385) who assert that: "[i]f religion is entirely indeterminate, such claims are unintelligible. They can only be proffered by someone who is fully confident that she can name and understand "religion" and "religious practices" in ways that are superior to prevailing understandings and that penetrate the false boundaries and distinctions other analysts erect between religion and non-religious phenomena".

The work of the scholars we have briefly examined-that of Sandal and Fox, Thomas, Huntington, Kubálková and Hurd-have many differences, both conceptual and defi- 
nitional. Three aspects are, however, common to them all: they (1) draw attention to religion's increased presence in international relations/International Relations, (2) maintain that traditional mainstream secular IR theories and concepts are unable to grasp this phenomenon adequately and (3) unwarrantedly overlook or undervalue religious factors in their analyses. Collectively, their analyses authoritatively undermine the traditional IR claim that to ignore or underestimate religion in international relations/IR is to wilfully ignore the plethora of empirical evidence of its importance in helping explain, at least, some international outcomes. Their accounts provide much thought and will help other scholars to hone and develop their own theories of the significance of religion and international relations/International Relations.

The final approach to the understanding of what religion does in international relations/International Relations (ir/IR) in this article is that 'religious soft power', which, although relatively recently advanced, may be the most currently influential approach to the topic. This is a constructivist approach which examines religion's impact on ir/IR. It is applied to both state and non-state actors. Haynes (2012) provides an overview of the religious soft power of the latter-focusing on American Evangelical Protestants, Roman Catholics, the Organisation of Islamic Cooperation and Sunni extremist groups, including al Qaeda and Lashkar-e-Taiba. Mandaville and Hamid (2018) and Öztürk (2021) examine the religious soft power of various governments, including those of Iran, Saudi Arabia, Jordan, Egypt, Morocco and Turkey, while Jödicke (2018) edited book looks at religious soft power in the Caucasus (that is, Turkey, Russia-Georgia relations, Azerbaijan and Armenia). Mandaville and Hamid argue that in Egypt, Morocco and Jordan, "religious institutions associated with the government have been promoted as purveyors of a "moderate Islam" capable of defeating the ideology of groups like ISIS". Thus, religious soft power can be a tool of both state and non-state actors. Öztürk (2021) looks at the case of Turkey and its Islam-informed foreign policy in the Balkans. These examples highlight the significance of religious transnational actors and of governments which also employ such a tool to encourage the spread and development of certain values and norms, which often impact on insecurity and order.

Kearn (2011) critiques the concept of religious soft power for its alleged ambiguity. Jödicke's edited book, Religion and Soft Power in the South Caucasus, states that his "contributors ... agreed to use the concept in an investigative sense and with a heuristic purpose, to identify a variety of constellations in which religions play a political role in transnational relations" (Jödicke 2018, p. 2). This highlights Kearn's critique of religious soft power: the unclear relationship between 'religion' and 'power'. For example, it is not necessarily the case that religious soft power-that is, the capacity to encourage an actor to behave in a certain way because of their religious beliefs-is necessarily 'soft' or benign. Instead, it can be maligned — think of the soft power of al Qaeda or Islamic State-and aligned with nationalism - as in the case of Turkey during the rule of President Erdoğan, Iran since the Islamic Revolution and the USA during the Trump presidency-and the overall result is an amalgam of soft and hard power which brings together both state and non-state actors for a variety of goals.

\section{Conclusions}

This article was concerned with how religion can usefully be brought into concepts, theories or paradigms of international relations. We saw that some scholars-such as, Huntington and Kubálková-believe that a new theory of IR is necessary to explain this. Fox and Sandal, on the other hand, contend that it is possible to accommodate the multiple ways in which religion and international relations interact by adapting existing IR theories to incorporate religion's influence. Finally, there are partial theories-such as those of Thomas, Hurd, and that of the various exponents of religious soft power, such as Mandaville and Hamid and Öztürk—who argue that religion's influence is most significant in specific ways and in specific contexts related to religion's power in relation to other aspects of that phenomenon. 
Overall, the article sought briefly to survey the scholarly study of 'religion and international relations/International Relations' at the start of the third decade of the 21st century. It argues that since the late 1970s, jumpstarted by the Islamic Revolution in Iran, the topic emerged. As it developed, it was identified/identifiable as a discrete area of study: 'religion and international relations/International Relations'. The article contends that its study was separated into two chronological periods: pre-9 September 2001 ('9/11') (late 1970s-11 September 2001) and post $9 / 11$ (post-9 September 2001). The first period was consequential to Iran's Islamic revolution, and, in addition, Huntington presented his influential 'clash of civilisations' paradigm. The second period, post-9 September 2001, saw a growing number of scholarly accounts focusing on religion in international relations. Many regarded 9/11 as pivotal and highly influential in helping remake US foreign policy, as for the next two decades, successive US governments seemed fixated on Islamist extremism and terrorism. Over time, however, characterised by the apparently significant diminution of the threat to the West of Islamist terrorism following the apparent demise of Islamic State and the fragmentation and reduction in influence of al Qaeda, new foci appeared in relation to the role(s) of religion in international relations/ International Relations.

We posed a question at the beginning of the article: When it comes to the association of religion and international relations, what do we know and how do we know it? To what extent do we need to change our perception of religion's (relatively minor but not marginal) impact on international relations in order to make better IR theory? Completing our brief survey, it seems clear that there is no succinct answer to these questions. In response to the first-What do we know? - we observed that empirical events help explain the rise and fall of concern with the role of religion in international relations, and that theoretical innovation needs to take 'real world' events into account to make better theory. In response to the second question-How do we know it?-we engaged with evidence that scholars focus on what they think is most important and that there are various methodological and theoretical ways to find out more about the issue that they examine. There is no single way to make theoretical progress in explaining and understanding the role(s) of religion in IR theory.

How then can we conclude our necessarily brief survey of the 'universe' of religion in IR theory? We inhabit a hierarchical and multipolar, but also interdependent and multilateral, global system. Its development is contextualised by events of the last three decades or so, that is, since the game-changing end of the Cold War. We have seen, however, that for IR theory, while religion is not a 'game changer', its various manifestations-expressed in the actions and reactions of both states and transnational non-state actors and captured in specific events, such as the Iranian revolution and especially $9 / 11$ — can, at times and in relation to certain issues, be highly significant with long-term ramifications affecting international relations in a number of ways and with various outcomes. It does not follow, however, that religion's 'return' to international relations/International Relations means that we must fundamentally adjust our understanding of how international relations 'works' or International Relations is theorised. IR's enduring fascination with states has not been sidelined by the advent - or return — of religion to the analytical frame. States are still highly important, and most are always or very often secular in their international foci and activities. The result is that when it comes to religion's impact on IR theory, the evidence suggests that existing IR theories have not (yet) been superseded, despite the fact that, collectively, they see little or no consistent significance for religion. Religion remains an intriguing but opaque component of how we understand international relations/International Relations.

Funding: This research received no external funding

Conflicts of Interest: The author declares no conflict of interest. 


\section{Notes}

1 Reus-Smit (2005, p. 211) defines culture as a broad "framework on inter-subjective meanings and practices that give a society a distinctive character...".

2 By April 2021, Thomas's 2005 book, The Global Transformation of Religion and the Transformation of International Relations. The Struggle for the Soul of the Twenty-First Century, had been cited just under 900 times, making it one of the most cited analyses of the role of religion in international relations (accessed on 7 May 2021).

3 'The number of casualties was enormous [although] uncertain. Estimates of total casualties range from 1,000,000 to twice that number.' https:/ / www.britannica.com/event/Iran-Iraq-War (accessed on 7 May 2021).

4 'International relations' (small i, small r) refers to relations between the world's governments. A more inclusive definition understands international relations as both more comprehensive and interdisciplinary. This 'broad' understanding of international relations not only engages with subject matter drawn from various fields of study but also includes a focus on both state and non-state actors, involving economics, politics, security studies and history. 'International Relations' (capital I, capital R) is the academic study of the discipline. One which has its theories and paradigms.

5 Hassner's most cited work on Google Scholar, with more than 300 citations on 26 March 2021, is War on Sacred Grounds, Cormell University Press, 2009.

6 RFIA has published many articles on international religious freedom over the years, including special issues in 2008 and 2013 https: / / www.tandfonline.com/toc/rfia20/current (accessed on 7 May 2021).

7 In this context, 'culture' may include religion but it not restricted to it. An example is the work of Huntington (1993, 1996) who uses the term 'civilisation' rather than 'culture'. Huntington wants to include various factors which make up the identity of discrete groups of people, including but not restricted to religion.

\section{References}

Barbato, Mariano, and Frederic Kratochwil. 2008. Towards a Postsecular Order? European Political Science Review 1: 320-36.

Beyer, Peter. 2014. Religion in the Context of Globalization. Essays on Concept, Form, and Political Implication. London and New York: Routledge.

Brown, Chris. 2005. Understanding International Relations, 3rd ed. Basingstoke: Palgrave.

Brubaker, Rogers. 2017. Between nationalism and civilizationism: The European populist moment in comparative perspective. Ethnic and Racial Studies 40: 1191-226. [CrossRef]

Calvert, Peter, and Susan Calvert. 2001. Politics and Society in the Third World: An Introduction. London: Longman.

Cesari, Jocelyne. 2021. We God's People: Christianity, Islam and Hinduism in the World of Nations. Cambridge: Cambridge University Press.

Dallmayr, Fred. 2004. Peace Talks—Who Will Listen? Notre Dame: Notre Dame University Press.

Doyle, Michael W. 1986. Liberalism and World Politics. The American Political Science Review 80: 1151-69. [CrossRef]

Fitzgerald, Timothy. 2011. Religion and Politics in International Relations. The Modern Myth. London and New York: Continuum.

Fox, Jonathan, and Nukhet Sandal. 2013. Religion in International Relations Theory: Interactions and Possibilities. London and New York: Routledge.

Habermas, Jürgen. 2006. Religion in the public sphere. European Journal of Philosophy 14: 1-25. [CrossRef]

Haynes, Jeffrey. 2005. Comparative Politics in a Globalizing World. Cambridge: Polity.

Haynes, Jeffrey. 2012. Religious Transnational Actors and Soft Power. Aldershot: Ashgate.

Haynes, Jeffrey. 2018. The United Nations Alliance of Civilisations and the Pursuit of Global Justice: Overcoming Western Versus Muslim Conflict and the Creation of a Just World Order. New York and Lampeter: Edwin Mellen Press.

Haynes, Jeffrey. 2019. From Huntington to Trump: Thirty Years of the Clash of Civilizations. New York: Lexington Books.

Haynes, Jeffrey. 2021. Trump and the Politics of Neo-Nationalism. The Christian Right and Secular Nationalism in America. London and New York: Routledge.

Hinnebusch, Raymond. 2005. International Relations of the Middle East. Edited by Louise Fawcett. Oxford: Oxford University Press, pp. 151-71.

Huntington, Samuel. 1993. The clash of civilisations? Foreign Affairs 72: 22-49. [CrossRef]

Huntington, Samuel. 1996. The Clash of Civilizations. New York: Simon and Schuster.

Hurd, Elizabeth Shakman. 2008. The Politics of Secularism in International Relations. Princeton: Princeton University Press.

Hurd, Elizabeth Shakman. 2015. Beyond Religious Freedom. Princeton: Princeton University Press.

Jenichen, Anne. 2021. Gender, Religion, and International Relations. In Handbook of Religion and International Relations. Edited by Jeffrey Haynes. London: Edward Elgar.

Jödicke, Ansgar. 2018. Religion and soft power in the Caucasus: An introduction. In Religion and Soft Power in the Caucasus. Edited by Ansgar Jödicke. London and New York: Routledge, pp. 1-20.

Kearn, David W. 2011. Hard Truths About Soft Power. Journal of Political Power 4: 65-85. [CrossRef]

Keohane, Robert. 1984. After Hegemony: Power and Discord in the World Political Economy. Princeton: Princeton University Press.

Kubálková, Vendulka. 2000. Toward an International Political Theology. Millennium 29: 675-704. [CrossRef] 
Kubálková, Vendulka. 2003. Toward an International Political Theology. In Religion in International Relations. The Return from Exile. Edited by Fabio Petito and Pavlos Hatzopoulos. New York: Palgrave, pp. 79-105.

Religion, State \& Society. 2021. Religion, State \& Society. In Special Issue: 'Right-Wing Nationalism and Religion: What Are the Connections and Why? Edited by Jeffrey Haynes. Abingdon: Routledge, vol. 49.

Mandaville, Peter, and Shadi Hamid. 2018. Islam as Statecraft. How Governments Use Religion in Foreign Policy. Washington, DC: Brookings Institution, Available online: https:/ / www.brookings.edu/product/the-geopolitics-of-religious-soft-power/ (accessed on 26 March 2021).

Marshall, Katherine. 2021. Religion and International Development. In Handbook of Religion and International Relations. Edited by Jeffrey Haynes. London: Edward Elgar.

McAlister, Melani. 2018. The Kingdom of God Has No Borders. A Global History of American Evangelicals. Oxford: Oxford University Press.

Merlini, Cesare. 2011. A Post-Secular World? Survival 53: 117-30. [CrossRef]

Öztürk, Ahmet Erdi. 2021. Religion, Identity and Power: Turkey and the Balkans in the Twenty-First Century. Edinburgh: Edinburgh University Press.

Petito, Fabio. 2009. Dialogue of Civilizations as an Alternative Model for World Order. In Civilizational Dialogue and World Order: The Other Politics of Cultures, Religions and Civilizations in International Relations. Edited by Michael Michalis and Fabio Petito. New York: Palgrave, pp. 47-67.

Philpott, Daniel, and Timothy Samuel Shah. 2016. State of The Field Essay. In Defense of Religious Freedom: New Critics of a Beleaguered Human Right. Journal of Law and Religion 31: 380-95. [CrossRef]

Pollinder, Simon. 2021. Towards A New Christian Political Realism? The Amsterdam School of Philosophy and the Role of Religion in International Relations. Unpublished. Doctoral Dissertation, VU Universitaat, Amsterdam, The Netherlands.

Reus-Smit, Christian. 2005. Constructivism. In Theories of International Relations, 3rd ed. Edited by Scott Burchill, Andrew Linklater Richard Devetak, Jack Donnelly, Mark Paterson, Christian Reus-Smit and Jaqui True. Basingstoke and New York: Palgrave Macmillan, pp. 161-87.

Ryan, Benedict. 2021. Christianism. In Routledge Handbook of Religion, Politics and Ideology. Edited by Jeffrey Haynes. London and New York: Routledge.

Saurin, Julian. 1995. The state in an age of globalisation: The end of international relations? The state and international theory in an age of globalisation. In Boundaries in Question: New Directions in International Relations. Edited by Andrew Linklater and John Macmillan. London: Continuum.

Snyder, Jack, ed. 2011. Introduction. In Religion and International Relations Theory. New York: Columbia University Press, pp. 1-21.

Thomas, Scott M. 2005. The Global Transformation of Religion and the Transformation of International Relations. The Struggle for the Soul of the Twenty-First Century. New York and Basingstoke: Palgrave Macmillan.

Thomas, Scottt M. 2014. Culture, Religion and Violence: Rene Girard's Mimetic Theory. Millennium-Journal of International Studies 43: 308-27. [CrossRef]

Toft, Monica Duffy, Daniel Philpott, and Timothy Samuel Shah. 2011. God's Century. Resurgent Religion and Global Politics. New York and London: W. W. Norton and Company.

Troy, Jodok. 2015. Little Do They Know. How (Not) to Theorise Religion and International Relations. E-International Relations. Available online: https: / / www.e-ir.info/2015/09/11/little-do-they-know-how-not-to-theorise-religion-and-international-relations / (accessed on 29 March 2021).

Waltz, Kenneth. 2010. Theory of International Politics. Long Grove: Waveland Pr Inc. First published 1979.

Wendt, Alexander. 1999. Social Theory of International Politics. Cambridge: Cambridge University Press. 